\title{
A Study on Knowledge, Attitudes, and Beliefs of Sri Lankan Forensic Practitioners towards Sexual Assault Survivors
}

\author{
Kumarasinghe $\mathrm{WGGB}^{1 *}$, Rowel WWJSM${ }^{2}$, Vadysinghe $\mathrm{AN}^{3}$ \\ ${ }^{1}$ Office of the Judicial Medical Officer, National Hospital, Kandy, Sri Lanka. \\ ${ }^{2}$ Victorian Institute of Forensic Mental Health, Victoria, Australia. \\ ${ }^{3}$ Department of Forensic Medicine, Faculty of Medicine, University of Peradeniya, Sri Lanka.
}

\begin{abstract}
Introduction: Sexual assault is a global problem with impacts on physical/ mental health. Sexual assault survivors experience negative social reactions such as stigmatization and blame attribution. Negative social reactions can lead to detrimental effects on mental health. It has been shown that negative reactions exist among the service providers for this group. This study examines the perception of forensic practitioners regarding sexual assault survivors.
\end{abstract}

Methodology: An online questionnaire comprised of 22 questions was sent out to forensic practitioners of Sri Lanka, who are the primary contacts of sexual assault survivors in the hospital setting. The questions addressed knowledge, attitudes and beliefs towards the sexual assault survivors.

Results: A sample of 51 responded to the questionnaire out of more than 100 invitees. Only $46 \%$ of the forensic practitioners reported that they never feel reluctant to examine sexual assault cases. An average of $71 \%$ responded positively to all the correct statements regarding knowledge. The average percentage of participants who responded negatively to the negative statements regarding attitudes/ believes was $57 \%$. A percentage of $39 \%$ responded as "agree" or "strongly agree" for the two positive statements regarding attitudes/ believes.

Conclusion: The findings of our study highlight the requirement of training programs and further studies to address the negative beliefs and attitudes among the primary health contacts of sexual assault survivors.

Keywords: Attitudes; forensic practitioner; sexual violence; survivors of sexual abuse

Received: 09 Nov 2021, Revised version accepted: 23 Nov 2021, Published: 31 Dec 2021. *Corresponding author: Kumarasinghe WGGB, $\triangle$ email: gk84keg@gmail.com (D) ORCID: https://orcid.org/0000-0002-7293-3956

Cite this article as: Kumarasinghe WGGB, Rowel WWJSM, Vadysinghe AN. A Study on Knowledge, Attitudes, and Beliefs of Sri Lankan Forensic Practitioners towards Sexual Assault Survivors. Medico-Legal journal of Sri Lanka. 2021;9(2):20-24. DOI: http://doi.org/10.4038/10.4038/mljsl.v9i2.7446

Copyright: @ 2019 with the Medico-legal Journal of Sri Lanka.

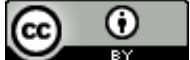

This is an open-access article distributed under the terms of the Creative Commons Attribution 4.0 International License, which permits unrestricted use, distribution, and reproduction in any medium provided the original author and source are credited.

\section{Introduction}

Sexual assault is a commonly encountered crime across the globe. A study which was conducted by the World Health Organization in 2018, utilizing data from 2000 to 2018, across 161 countries, revealed that approximately $30 \%$ of women have been subjected to sexual and/or physical violence.[1] Similarly, a survey done in Sri Lanka in 2019 showed that $24.9 \%$ of women had experienced physical and/or sexual intimate partner violence or non-partner sexual violence.[2] Also, sexual assault is a serious public health problem and causes significant mental health problems, such as anxiety, depression, and post-traumatic stress disorder.[3,4]

Following a sexual assault, the survivors would contact several community agencies for assistance, such as the legal, medical, and mental health systems.[5] In the hospital setting, victims are referred to forensic, medical and psychological assessment. In Sri Lanka, forensic practitioners take the leading role during the assessment. A forensic examination is carried out as early as possible following the index event. Such examination usually takes approximately 2 hours. 
It has been shown that negative attitudes exist towards sexual assault survivors among community groups such as police officers and physicians.[5] Myths related to cultural beliefs, blame attribution, and core beliefs can result in negative reactions. According to previous studies, such negative reactions are associated with more post-traumatic symptoms, stigmatization and secondary traumatization of the victims.[4]

In the above context, this study was designed to understand the knowledge, attitudes and beliefs of forensic practitioners of Sri Lanka, towards sexual assault survivors. Forensic practitioners have regular contact with the above group of patients in the hospital setting. Gaining a deeper understanding would be helpful to design interventions and strategies that will improve the caring of sexual assault survivors. This is the first study done in Sri Lanka to address this issue.

\section{Methodology}

The Forensic practitioners in Sri Lanka including postgraduate (PG) trainees and Medical OfficersMedicolegal from various parts of the country were invited to participate in a cross-sectional, anonymous online survey. The online questionnaire was sent out via email. This email contained an invitation letter and a link to the questionnaire. This invitation letter included a summary of information about the study, rationale for the study and the ethical aspects. Ethical clearance for the study was obtained from the Ethics Review Committee of National Hospital, Kandy.

The questionnaire was composed of 22 questions, including, six questions on practice and demographics, six questions on related knowledge, and ten questions on beliefs and attitudes towards sexual assault survivors. Answers for the questions regarding knowledge, attitude and beliefs were rated by a Likert scale as "strongly disagree", "disagree", "neutral", "agree" and "strongly agree". All the questions related to knowledge carried correct statements. In the questions regarding beliefs/attitudes, the first eight had negative statements and the last two had positive statements. The positive responses for correct/positive statements were correct or favourable. Also, negative responses for the negative/incorrect statements were favourable.

The questionnaire was developed with the guidance of the Attitudes toward Rape Victims Scale (ARVS) revised by Ward and was modified according to the Sri Lankan context [6]. The original scale is a 25item scale, which assesses favourable/unfavourable attitudes toward rape victims on victim blame, credibility, deservingness, denigration, and trivialization. The rationale for using ARVS for the development of the questionnaire is its proven reliability, validity and cross-cultural suitability $[6,7]$.

All responses were recorded automatically via the survey platform and were downloaded to Microsoft excel. Categorical variables were reported using frequencies, while continuous data were analysed using means and standard deviations. For group comparisons of categorical variables, chi-square analyses were conducted.

\section{Results}

More than 100 forensic practitioners were invited to participate in the study. Only 51 had responded to the survey and 50 had completed the questionnaire properly, one was incomplete. The majority of the participants were male $(78 \%, \mathrm{n}=39)$ and $58 \%(\mathrm{n}=$ $29)$ were postgraduate trainees and $42 \%$ were medical officers-medicolegal.

The majority of the participants $(46 \%, \mathrm{n}=23$.) had a work experience of $1-4$ years, $24 \%(n=12)$ had more than 10 years of experience, $16 \%(n=08)$ had work experience of 4-9 years and $14 \%(n=07)$ had worked less than a year. A percentage of $78 \%$ had examined more than 10 cases in their career. Two participants had never examined any cases of sexual assault. In our cohort, $64 \%$ reported that they have never testified in a legal proceeding for a case of sexual assault.

In our sample, $46 \%$ reported that they never had any reluctance to examine sexual assault cases because of the possibility of being required to testify in legal proceedings. Further, it was revealed that $60 \%$ out of the PG trainees and $30 \%(n=15)$ out of the medical officers reported never being reluctant to examine sexual assault cases. Also, $60 \%(n=30)$ of the forensic practitioners who had more than four years of experience never had been reluctant to examine victims of sexual assault and that value for the forensic practitioners with less than four years of experience had been $36.7 \%$. Out of two participants who claimed that they had never examined any sexual assault cases, one reported being reluctant to examine sexual assault cases virtually all the time and the other reported being reluctant most of the time.

Table 01 is a summary of the responses of the participants on knowledge, beliefs and attitudes towards sexual assault victims. 
Table 01: Responses of the participants on knowledge, beliefs and attitudes towards sexual assault victims.

\begin{tabular}{|c|c|c|c|c|}
\hline \multirow[t]{2}{*}{ Questions } & \multirow{2}{*}{$\begin{array}{l}\text { Strongly Agree } \\
\text { agree } \\
\mathbf{n}(\%) \quad \mathbf{n}(\%) \\
\end{array}$} & \multirow{2}{*}{$\begin{array}{r}\text { Neutral } \\
\text { n }(\%)\end{array}$} & \multicolumn{2}{|c|}{$\begin{array}{r}\text { Disagree Strongly } \\
\text { disagree }\end{array}$} \\
\hline & & & n $(\%)$ & n $(\%)$ \\
\hline $\begin{array}{l}\text { 1. Parent's/Guardian's } \\
\text { consent should be } \\
\text { obtained prior to medico- } \\
\text { legal examination of a } \\
\text { case of child sexual } \\
\text { abuse }\end{array}$ & $25(50) 18(36)$ & $01(02)$ & $05(10)$ & $01(02)$ \\
\hline $\begin{array}{l}\text { 2. Psychiatry referral } \\
\text { should be done even the } \\
\text { consent is not taken }\end{array}$ & 07 (14) 22 (44) & $08(16)$ & $11(22)$ & $02(04)$ \\
\hline $\begin{array}{l}\text { 3. STD referral should be } \\
\text { done even the consent is } \\
\text { not taken }\end{array}$ & 08 (16) 21 (42) & $11(22)$ & $08(16)$ & $02(04)$ \\
\hline $\begin{array}{l}\text { 4. Clinical case conference } \\
\text { should be held for child } \\
\text { sexual abused cases. }\end{array}$ & 08 (16) $27(54)$ & $11(22)$ & $03(06)$ & $01(02)$ \\
\hline $\begin{array}{l}\text { 5. Institutional case } \\
\text { conference could reduce } \\
\text { the risk of future abuse. }\end{array}$ & $10(20) 22(44)$ & $11(22)$ & $05(10)$ & $01(02)$ \\
\hline $\begin{array}{l}\text { 6. Post traumatic problems } \\
\text { of sexual assault cases } \\
\text { should with be dealt by } \\
\text { linking them with routine } \\
\text { social service agencies } \\
\text { (psychiatrists, } \\
\text { counsellors, NCPA, } \\
\text { probation) }\end{array}$ & $14(28) 31(62)$ & $02(04)$ & $02(04)$ & $00(00)$ \\
\hline $\begin{array}{l}\text { 7. Victims increase their } \\
\text { likelihood of being } \\
\text { attacked by behaviours } \\
\text { such as wearing } \\
\text { revealing clothes, } \\
\text { behaving in a suggestive } \\
\text { manner and etc? }\end{array}$ & $08(16) 15$ (30) & $13(26)$ & $12(24)$ & $02(04)$ \\
\hline $\begin{array}{l}\text { 8. During a sexual assault a } \\
\text { woman should do } \\
\text { everything in her power } \\
\text { to resist }\end{array}$ & $06(12) 20(40)$ & $10(20)$ & $10(20)$ & $02(04)$ \\
\hline $\begin{array}{l}\text { 9. Most sexual assaults } \\
\text { involves violence and } \\
\text { physical injury }\end{array}$ & 03 (06) 07 (14) & 07 (14) & $33(66)$ & $00(00)$ \\
\hline $\begin{array}{l}\text { 10. Sexual assaults happen } \\
\text { when women go out } \\
\text { alone at night and in } \\
\text { unsafe places }\end{array}$ & $04(08) 10(20)$ & $11(22)$ & $21(42)$ & $03(06)$ \\
\hline $\begin{array}{l}\text { 11. Most of the perpetrators } \\
\text { are strangers }\end{array}$ & $00(00) 01(02)$ & $03(06)$ & $34(68)$ & $12(24)$ \\
\hline $\begin{array}{l}\text { 12. A woman could not be } \\
\text { sexually assaulted by } \\
\text { someone she previously } \\
\text { knew or had sex with }\end{array}$ & $01(02) 02(04)$ & $04(08)$ & $25(50)$ & $18(36)$ \\
\hline $\begin{array}{l}\text { 13. A victim who looks calm } \\
\text { is less likely to have } \\
\text { psychological problems } \\
\text { later on }\end{array}$ & $00(00) 05(10)$ & $08(16)$ & $25(50)$ & $12(24)$ \\
\hline $\begin{array}{l}\text { 14. Commonly sexual } \\
\text { assault victims will be } \\
\text { hysterical, shaky and } \\
\text { distraught }\end{array}$ & 02 (04) 07 (14) & $22(44)$ & $16(32)$ & $03(06)$ \\
\hline $\begin{array}{l}\text { 15. If I talked to someone } \\
\text { who was sexually } \\
\begin{array}{l}\text { assaulted, I } \\
\text { become upset. }\end{array}\end{array}$ & $01(02) 12(24)$ & $12(24)$ & $15(30)$ & $10(20)$ \\
\hline $\begin{array}{l}\text { 16. feel the emotional } \\
\text { torment a sexual assault } \\
\text { victim suffers when } \\
\text { dealing with the police/ } \\
\text { trial }\end{array}$ & 09 (18) 17 (34) & $15(30)$ & $06(12)$ & $03(006$ \\
\hline
\end{tabular}

An average of $70 \%(n=35)$ responded as "agree" or "strongly agree" for all the correct statements regarding knowledge. The average percentage of the participants who responded as "disagree"/ "strongly disagree" for the negative statements regarding attitudes/ believes was $58 \%(n=29)$. A percentage of $40 \%$ responded as "agree" or "strongly agree" for the two positive statements regarding attitudes/ believes. Only 24\% ( $n=12)$ disagreed with the statement "during a sexual assault a woman should do everything in her power to resist". Further, only $28 \%$ $(n=14) \quad$ disagreed with the statement "victims increase their likelihood of being attacked by behaviours such as wearing revealing clothes, behaving in a suggestive manner and etc".

There was no significant difference between PG trainees and medicolegal medical officers regarding positive responses to positive statements regarding knowledge, also negative responses for negative statements $(p=0.999>0.05)$ and $(p=0.996>0.05)$ respectively. Also, there was no significant difference in responses for the positive and negative statements between those who had less than 4 years of experience and more than 4 years of experience in forensic $\quad(p=0.999>0.5) \quad$ and $\quad(p=0.993>0.05)$ respectively.

\section{Discussion}

The World Health Organisation defines sexual assault/sexual violence as "Any sexual act, attempt to obtain a sexual act, unwanted sexual comments or advances, or acts to traffic or otherwise directed against a person's sexuality using coercion, by any person regardless of their relationship to the victim, in any setting, including but not limited to home and work".[8] It includes rape, attempted rape, touching, sexual harassment, threatened sexual violence and sexual slavery.[8]

Sexual assaults have been shown to have effects on the mental and physical health of the survivors.

These include long-lasting difficulties in the quality of their sexual experiences, reproductive or other sexual health problems including sexually transmitted infections, unwanted pregnancies and mood/ anxiety disorders. Among mental disorders depressive disorder and post-traumatic disorder are common. It has been reported that about one-third of rape victims experience a major depressive episode in their lifetime.[3] A study revealed that $94 \%$ of sexual assault survivors experience post-traumatic symptoms within 2 weeks of assault and $47 \%$ within three months. Negative social reactions, including stigmatizing responses are associated with more post-traumatic symptoms.[4] 
It has been shown that negative attitudes exist towards sexual assault survivors among community groups such as police officers and physicians [5]. A study which was done in Hong-Kong involving doctors who work in Emergency Departments revealed that $36 \%$ of them believed that "a woman should be responsible for preventing her rape". Also, in the same study, only $40 \%$ of doctors had reported that "they would not avoid handling sexual assault cases if they were given the choice". Investigators believed that it could be due to lack of proper training and a lack of experience in handling the above cases. Hence, they have highlighted the importance of formal training programmes to improve the knowledge and attitudes of doctors towards sexual assault survivors in order to prevent secondary victimization.[5]

In our study, only $46 \%$ of the forensic practitioners reported that they never feel reluctant to examine sexual assault cases, because of the possibility of being required to testify in legal proceedings. In other words, $54 \%$ had some degree of reluctance in examining sexual assault cases. This could be due to a lack of experience and lack of training.

The PG trainees were less reluctant to examine victims of sexual assault compared to the Medical officers- medicolegal though the difference was not significant. Also, those who had more years of experience were less reluctant to examine sexual assault cases. These findings also support the hypothesis that experience and proper training can influence the way in which medical practitioners respond to such victims.

The favourable response rate was higher in the knowledge domain and that in the attitudes/ believes domain was comparatively low. Thus, the majority were knowledgeable about the correct steps of management. However, they have negative beliefs such as blame towards the victims. For example, a significantly low percentage of participants had disagreed with the statements, "during a sexual assault a woman should do everything in her power to resist" and "victims increase their likelihood of being attacked by behaviours such as wearing revealing clothes, behaving suggestively, etc". This could be due to cultural and societal influence. In the Sri Lankan cultural context, women bear a greater weight on social expectations. They are expected to wear and behave appropriately to maintain dignity. Studies have shown that negative social reactions are associated with more posttraumatic symptoms, secondary victimization and attribution of blame to the sexual assault victims.[4] There was no statistically significant difference between PG trainees vs. medical officers-medico legal and those who had less than 4 years of experience vs. those who had more than 4 years of experience, in terms of response rates to attitude/ beliefs and knowledge domains.

The findings of our study highlight the requirement of interventions to address the negative attitudes/ beliefs of the forensic practitioners who are the primary contacts of sexual violence survivors in the hospital setting of Sri Lanka. These interventions include clinical audits and training activities like lectures and online interactive learning sessions which could be incorporated into the existing training programs and continuous professional development. Also, further studies are needed to explore the effects of knowledge and attitudes of forensic practitioners towards the outcome of sexual assault victims.

\section{Conclusions}

Forensic practitioners are the leading group of health care providers who encounter sexual assault victims. Lack of proper training and experience adversely affect the willingness of forensic practitioners to handle such cases. However, knowledge and attitudes towards sexual assault victims are not affected by their years of experience or seniority. Unfavourable attitudes towards such victims are influenced by cultural beliefs. Proper training and professional development programmes are needed to be incorporated into the existing system to overcome these shortcomings when providing care.

\section{Limitations}

There are several limitations in this study. The main limitation is the small sample size that prevents the ability to draw strong conclusions. The small sample size restricted the ability of our study to detect the differences in the response rates among different groups. Also, the questionnaire of the study was not tested independently for validity and reliability, though the questions were constructed based on a previously validated survey questionnaire in other countries. The response bias is the other limitation. We administered a self-rated questionnaire and the participants tend to answer what is expected by the investigators rather than what they actually feel/ think.

\section{Disclosure statement}

Conflicts of interest: The authors declare that they have no conflicts of interest.

Funding: None

\section{References}


1. Violence against women Prevalence Estimates, 2018. WHO Geneva. 2021 Mar. [cited 2021 Sep 2]; [about 112 p.]. Available from: http://www.statistics.gov.lk/Resource/refference /WWS_2019_Final_Report

2. Women's Well-being Survey, 2019. Department of Census and Statistics, Sri Lanka. 2020 Oct [cited 2021 Sep 2]; [about 220 p.]. Available from:

http://www.statistics.gov.lk/Resource/refference /WWS_2019_Final_Report

3. Neilson EC, Norris J, Bryan AEB, Stappenbeck CA. Sexual Assault Severity and Depressive Symptoms as Longitudinal Predictors of the Quality of Women's Sexual Experiences. JSMT. 2017 Jul [cited 2021 Sep 2]; 43(5): [about 15 p.]. Available from: https://pubmed.ncbi.nlm.nih.gov/27390081/

4. Ullman SE, Filipas HH. Predictors of PTSD symptom severity and social reactions in sexual assault victims. JTS. 2001 Apr [cited 2021 Sep 2]; 14(2): [about 20 p.]. Available from: https://link.springer.com/article/10.1023/A:1011 125220522

5. Wong AYS, Wong TW, Lau PF, Lau CC. Attitude towards rape among doctors working in the emergency department. European Journal of Emergency Medicine: Official Journal of the
European Society for Emergency Medicine. 2002 Jun [cited 2021 Sep 2]; 9(2): [about 3 p.]. Available from: https://pubmed.ncbi.nlm.nih.gov/12131633/

6. Ward C. The attitudes toward rape victims scale: construction, validation, and cross-cultural applicability. Psychology of Women Quarterly. 1988 Jun [cited 2021 Sep 2]; 12(2): [about 19 p.]. Available from: https://journals.sagepub.com/doi/10.1111/j.1471 -6402.1988.tb00932.x

7. Ward C, Newlon B, Krahe B, Myambo K, Payne M, Tastan Y, Yuksel S, Ghadially R, Kumar U, Lee HB, Cheung FM, Upadhyaha S, Patnoe JM Kirby, C., Vasquez Gomez, A, Parra E. and Colosio C. The attitudes toward rape victims scale: psychometric data from 14 countries. Social and Behavioral Sciences Documents.1992 [cited 2021 Sep 210]; 18(2877). Available from: http://opus.kobv.de/ubp/volltexte/2009/3449/

8. World Health Organization [homepage on the Internet]. Violence against women - Intimate partner and sexual violence against women, Geneva, World Health Organization, 2011[updated 2021 Mar 9; cited 2021 Sep 2]. WHO Office Geneva; [about 4 screens]. Available from: https://www.who.int/newsroom/fact-sheets/detail/violence-against-women 